Volume 3 Issue 1, March 2018: pp. 1-10. Copyright @ LamLaj. Faculty of Law, Lambung Mangkurat University, Banjarmasin, South Kalimantan, Indonesia. ISSN: 2502-3136 | e-ISSN: 2502-3128.

Open Access at: http://lamlaj.ulm.ac.id/web/

\title{
AKIBAT HUKUM KETERLAMBATAN PENDAFTARAN PERALIHAN HAK ATAS TANAH TERHADAP AKTA YANG DIBUAT OLEH PEJABAT PEMBUAT AKTA TANAH
}

\author{
Islina Yuliyanti ${ }^{1}$ Yulia Qamariyanti $^{2}$ Mahyuni $^{3}$ \\ Alumni Program Magister Kenotariatan Fakultas Hukum Universitas Lambung \\ Mangkurat. Jl.Brigjend H.Hasan Basri Komplek Banjarmasin 70123 Indonesia \\ Fax:05114321658+E-mail :islinayulianti@yahoo.com \\ Fakultas Hukum Universitas Lambung Mangkurat. Jl.Brigjend H.Hasan Basri \\ Komplek Banjarmasin 70123 Indonesia \\ Fax:05114321658+E-mail :yuliaqamariyanti@yahoo.com \\ Fakultas Hukum Universitas Lambung Mangkurat. Jl.Brigjend H.Hasan Basri \\ Komplek Banjarmasin 70123 Indonesia Fax: 05114321658
}

Submitted : 25/01/2018 Reviewed 27/02/2018 Accepted:31/03/2018

\begin{abstract}
From the results of this research it can be concluded as follows, firstly, in the making process of the deed of transfer, at the latest 7 (seven) working days from the signing date of the deed, the Land Deed Making Official must submit the deed together with the related documents to the Land Office for being registered. If such period is ignored it will arise legal consequence the Land Deed Making Official to the registration of the deed of transfer of land right. Secondly, for maintaining the order on the process of registration of the deed of transfer of land right at the Land Office of Banjarmasin Municipality and to avoid the related parties to be disadvantaged, there should be strict sanction sit is also subject to the Land Deed Making Official Officials in Banjarmasin Mmunicipality will repeat such violation. The regulation certifies that such matter is compulsory for the Lang Deed Making Officials to comply with. Since it is related with the enforcement of legal provision, the violation there to shall be subject to administrative sanction in a from of written warning up to termination from the position as the Land Deed Making Official, and it is also subject to claim for compensation by the parties who suffer loss incurred due to the ignorance of the said provision.
\end{abstract}

Keywords: Legal Consequence; Late Registration; Transfer of Land Right

Abstrak: Dalam proses pembuatan akta peralihan maka dalam waktu selambat- 


\begin{abstract}
lambatnya 7 (tujuh) hari kerja sejak tanggal ditandatanganinya akta yang bersangkutan, PPAT wajib menyampaikan akta yang dibuatnya berikut dokumendokumen yang bersangkutan kepada Kantor Pertanahan untuk didaftar. Apabila jangka waktu tersebut diabaikan maka akan menimbulkan beberapa akibat hukum terhadap akta peralihan tersebut.Maka untuk lebih terjaganya ketertiban dalam proses pendaftaran peralihan hak atas tanah di Kantor Pertanahan Kota Banjarmasin dan juga agar pihak-pihak yang bersangkutan tidak di rugikan harus adanya sanksi tegas agar PPAT di Kota Banjarmasin tidak melakukan lagi pelanggaran tersebut, karena didalam peraturan itu sendiri sudah mengatakan bahwa hal tersebut adalah "wajib” bagi PPAT. Karena hal di atas menyangkut masalah pelaksanaan dari suatu ketentuan hukum, dikenakan tindakan administrasi berupa teguran tertulis sampai pemberhentian dari jabatannya sebagai PPAT, dengan tidak mengurangi kemungkinan dituntut ganti kerugian oleh pihak-pihak yang menderita kerugian yang diakibatkan oleh diabaikannya ketentuan-ketentuan tersebut.
\end{abstract}

Kata-kata kunci: akibat hukum; keterlambatan pendaftaran; peralihan hak atas tanah

\section{PENDAHULUAN}

Pembangunan yang dilaksanakan pemerintah dalam upaya meningkatkan pelayanan kepada masyarakat, baik untuk prasarana maupun sarana, memerlukan tanah. Demikian pula seluruh lapisan masyarakat, dalam usaha meningkatkan kualitas hidupnya memerlukan tanah. Oleh karena itu gejala hubungan timbal balik antara manusia dengan tanah ini dilihat dari satu sudut: manusia semakin lama semakin meningkat mutu dan jumlahnya (kualitas dan kuantitasnya) sehingga kebutuhan manusia akan tanah yang relatif semakin sempit ini, semakin bertambah. Menghadapi hubungan timbal balik ini serta untuk menata hubungan tersebut, dicetuskan gagasan oleh Pemerintah untuk menyelenggarakan pendataan penguasaan tanah yang selalu mutakhir, terutama untuk keperluan perpajakan, perencanaan dan pengawasan serta dibalik itu juga bagi masyarakat memberikan jaminan kepastian hukum mengenai hak-hak atas tanahnya.

Peralihan hak atas tanah adalah perbua- tan hukum pemindahan hak atas tanah yang dilakukan dengan sengaja supaya hak tersebut terlepas dari pemegangnya semula dan menjadi hak pihak lain. Sejak berlakunya UU Nomor 5 Tahun 1960 tentang Pokok-pokok Agraria (UUPA), peralihan hak atas tanah dapat dilakukan melalui jual beli, penukaran, penghibahan, pemberian dengan wasiat, pemberian menurut adat dan perbuatan lain yang dimaksudkan untuk memindahkan hak milik. Menurut Pasal 37 ayat 1 Peraturan Pemerintah Nomor 24 Tahun 1997 tentang Pendaftaran Tanah, ditegaskan bahwa:

"Peralihan hak atas tanah dan hak milik atas satuan rumah susun melalui jual beli, tukar menukar, hibah, pemasukan data perusahaan dan perbuatan hukum pemindahan hak lainnya, kecuali pemindahan hak melalui lelang hanya dapat didaftarkan jika dibuktikan dengan akta yang dibuat oleh PPAT yang berwenang menurut ketentuan peraturan perundang-undangan yang berlaku." 
Pembuktian bahwa hak atas tanah tersebut dialihkan, maka harus dibuktikan dengan suatu akta yang dibuat oleh dan dihadapan Pejabat Pembuat Akta Tanah yaitu akta jual beli, tukar menukar, hibah, pemasukan data perusahaan dan perbuatan hukum pemindahan hak lainnya, yang akan dijadikan dasar pendaftaran perubahan data pendaftaran tanah sebagaimana dimaksud dalam ketentuan Pasal 95 ayat 1 huruf a Peraturan Menteri Agraria/Kepala Badan Pertanahan Nasional Nomor 3 Tahun 1997 tentang Peraturan Jabatan Pejabat Pembuat Akta Tanah. Akta Peralihan yang dibuat dihadapan PPAT tersebut bertujuan untuk memberikan kepastian hukum kepada pemegang hak atas suatu bidang tanah (pembeli tanah). Pejabat Pembuat Akta Tanah sebagai pejabat umum yang diberi wewenang untuk membuat akta-akta dalam peralihan hak atas tanah, akta pembebanan serta surat kuasa pembebanan hak tanggungan, juga bertugas membantu Kepala Kantor Pertanahan Nasional dalam melaksanakan pendaftaran tanah dengan membuat akta-akta tertentu sebagai bukti telah dilakukannya perbuatan hukum tertentu mengenai hak atas tanah dan atau bangunan yang akan dijadikan dasar bagi bukti pendaftaran tanah.

Pendaftaran tanah sebagaimana yang diatur dalam Pasal 40 Peraturan Pemerintah Nomor 24 Tahun 1997 tentang Pendaftaran Tanah yakni:

(1) Selambat-lambatnya 7 (tujuh) hari kerja sejak tanggal ditandatanganinya akta yang bersangkutan, PPAT wajib menyampaikan akta yang dibuatnya berikut dokumen-dokumen yang bersangkutan kepada Kantor Pertanahan untuk didaftar.

(2) PPAT wajib menyampaikan pemberitahuan tertulis mengenai telah disampaikannya akta sebagaimana dimaksud pada ayat
(1) kepada para pihak yang bersangkutan.

Tulisan ini menggali lebih dalam tentang pendaftaran peralihan hak atas tanah yang dirumuskan dalam:

1. Bagaimana akibat hukum terhadap keterlambatan pendaftaran peralihan hak atas tanah yang aktanya didaftarkan melebihi jangka waktu 7 (tujuh) hari?

2. Bagaimana sanksi yang diterapkan terhadap Pejabat Pembuat Akta Tanah yang mendaftarkan aktanya melebihi jangka waktu 7 (tujuh) hari oleh Badan Pertanahan Kota Banjarmasin?

\section{METODE}

\section{Jenis Penelitian}

Jenis penelitian yang digunakan adalah penelitian hukum empiris, penelitian yang memperoleh data primer melalui penelitian lapangan. Untuk mendukung penelitian lapangan, dilakukan penelitian kepustakaan untuk memperoleh data sekunder, yang terdiri dari bahan hukum primer, bahan hukum sekunder dan bahan hukum tersier.

\section{Sifat Penelitian}

Penelitian bersifat deskriptif yaitu dengan menggambarkan atau memaparkan dan menjelaskan suatu keadaan yang didasarkan pada gejala-gejala serta fakta-fakta yang diperoleh kemudian dikaji berdasarkan bahan kepustakaan yang berhubungan dengan masalah yang diteliti.

\section{Jenis Data}

Jenis data dalam penelitian ini, meliputi:

1. Data Primer adalah data yang didapatkan dilapangan

2. Data Sekunder yang meliputi:

a. Bahan hukum primer

1) Undang-Undang Dasar Negara Republik Indonesis Tahun 1945 
2) Undang-Undang Nomor 5 Tahun 1960 tentang Pokok-pokok Agraria

3) Peraturan

Pemerintah Nomor 24 Tahun 1997 tentang Pendaftaran Tanah

4) Peraturan Pemerintah Nomor 37 Tahun 1998 tentang Jabatan Pejabat Pembuat Akta Tanah (PPAT)

5) Keputusan Presiden Nomor 10 Tahun 2001 tentang Pelaksanaan Otonomi Daerah Di Bidang Pertanahan Peraturan Menteri Negara Agraria/Kepala Badan Pertanahan Nasional Nomor3 Tahun 1997 tentang Peraturan Pelaksanaan

6) Peraturan Menteri Negara Agraria Nomor 1 Tahun 2006 tentang Ketentuan Pelaksanaan Peraturan Pemerintah Nomor 37 Tahun 1998 tentang Peraturan Jabatan Pejabat Pembuat Akta Tanah

7) Peraturan Menteri Agraria Nomor 3 Tahun 1997 tentang Ketentuan Pelaksanaan Peraturan Pemerintah Nomor 24 Tahun 1997 Tentang Pendaftaran Tanah

b. Bahan hukum sekunder adalah bukubuku, diktat, tesis, artikel internet, yang ada kaitannya dengan masalah yang diteliti. ${ }^{1}$ Penelitian ini juga menggunakan Anggaran Dasar Ikatan Pejabat Pembuat Akta Tanah Indonesia dan Anggaran Rumah Tangga Ikatan Pejabat Pembuat Akta Tanah Indonesia dan Kode Etik Profesi Pejabat Pembuat Akta Tanah.

3. Bahan hukum tersier yakni bahan yang

1 Zainuddin Ali. 2009. Metode Penelitian Hukum. Jakarta: Sinar Grafika, hlm. 47 memberikan petunjuk maupun penjelasan terhadap bahan hukum primer dan sekunder. $^{2}$

\section{Lokasi dan Objek Penelitian}

1. Lokasi Penelitian

Lokasi Penelitian adalah Kota Banjarmasin, wilayah atau daerah kerja Pejabat Pembuat Akta Tanah yang diteliti termasuk dalam wilayah kerja Kantor Pertanahan Kabupaten/Kotamadya Banjarmasin.

2. Objek Penelitian

Objek penelitian adalah Pejabat Pembuat Akta Tanah (PPAT), yang membuat aktaakta tanah sehubungan dengan tujuan dari penelitian peneliti di wilayah atau daerah kota Banjarmasin.

Teknik Pengumpulan, Pengolahan dan Analisis Bahan Hukum

Dalam penelitian ini peneliti lebih banyak menggunakan data primer yang berasal dari narasumber dan wawancara di samping studi dokumen atau bahan pustaka sebagai pelengkap. Wawancara yaitu cara memperoleh informasi dengan bertanya langsung pada pihak-pihak yang diwawancarai terutama orang-orang yang berwenang, mengetahui dan terkait dengan tanggung jawab pejabat pembuat akta tanah dalam hal terjadi kelalain terhadap pendaftaran akta pertanahan. Sistem wawancara yang dipergunakan adalah wawancara bebas terpimpin, artinya terlebih dahulu dipersiapkan daftar pertanyaan sebagai pedoman tetapi masih dimungkinkan adanya variasi pertanyaan yang disesuaikan dengan situasi pada saat wawancara dilakukan. ${ }^{3}$ Daftar pertanyaan yaitu daftar pertanyaan yang

2 Ibid, hlm. 52

3 Soetrisno Hadi. 1985. Metodologi Reseacrh Jilid II. Yogyakarta: Yayasan Penerbit Fakultas Psikologi Universitas Gajah Mada, hlm. 26 
diajukan kepada orang-orang yang terkait dengan tanggungan PPAT dalam hal terjadi pelanggaran etika profesi, untuk memperoleh jawaban secara tertulis. Daftar pertanyaan diberikan kepada pihak Kantor Badan Pertanahan Kota Banjarmasin dan Ikatan Pejabat Pembuat Akta Tanah (IPPAT) Kota Banjarmasin serta Notaris selaku Pejabat Pembuat Akta Tanah di Wilayah Kota Banjarmasin.

Bahan hukum yang diperoleh dari studi dokumen pada dasarnya merupakan bahan hukum yang dianalisis secara kualitatif, yaitu setelah bahan hukum terkumpul kemudian dituangkan dalam bentuk uraian logis dan sistematis, selanjutnya dianalisis untuk memperoleh kejelasan penyelesaian masalah, kemudian ditarik kesimpulan secara deduktif, yaitu dari hal yang bersifat umum menuju hal yang bersifat khusus. ${ }^{4}$ Dalam penarikan kesimpulan, peneliti menggunakan metode deduktif. Metode deduktif adalah suatu metode yang berhubungan dengan permasalahan yang diteliti dari peraturan-peraturan atau prinsip-prinsip umum menuju penulisan yang bersifat khusus.

\section{ANALISIS DAN PEMBAHASAN}

\section{Akibat Hukum terhadap Keterlambatan Pendaftaran Peralihan Hak Atas Tanah yang Aktanya Didaftarkan Melebihi Jang- ka Waktu 7 (Tujuh) Hari}

Berdasarkan Peraturan Pemerintah Nomor 24 Tahun 1997 tentang Pendaftaran Tanah, menyebutkan dengan tegas bahwa dalam melaksanakan tugas pendaftaran tanah dilakukan oleh Kepala Kantor Pertanahan dibantu oleh Pejabat Pembuat Akta Tanah (PPAT). Sehingga sering orang mengatakan bahwa peran PPAT sebagai "notarisnya per-

4 Ibid, hlm. 10 tanahan". Berdasarkan Peraturan Pemerintah Nomor 37 Tahun 1998 tentang Peraturan Jabatan Pembuat Akta Tanah (PPAT), maka untuk menjamin kepastian hukum hak-hak atas tanah, kepada pemerintah diperintahkan oleh undang-undang untuk melaksanakan pendaftaran tanah dan kepada PPAT diberi wewenang untuk membuat alat bukti mengenai perbuatan hukum tertentu mengenai Hak Atas Tanah dan Hak Milik Satuan Rumah Susun.

Akta PPAT adalah akta yang secara konkret dan kontan berlaku sebagai bukti telah dilakukannya suatu perbuatan hukum berpindahnya hak yang memenuhi syarat untuk didaftarkan untuk didaftarkan dalam administrasi pendaftaran tanah sehingga memenuhi syarat publisitas. Akta otentik pada hakikatnya memuat kebenaran formal sesuai dengan apa yang diberitahukan para pihak kepada PPAT. Namun PPAT mempunyai kewajiban untuk memastikan bahwa apa yang termuat dalam Akta PPAT sungguh-sungguh telah dimengerti dan sesuai dengan kehendak para pihak, yakni dengan cara membacakannya sehingga menjadi jelas isi Akta PPAT, serta memberikan akses terhadap informasi, termasuk akses terhadap peraturan perundang-undangan yang terkait bagi para pihak penandatangan akta. Dengan demikian, para pihak dapat menentukan dengan bebas untuk menyetujui atau tidak menyetujui isi Akta PPAT yang akan ditandatanganinya.

Peralihan hak atas tanah itu sendiri adalah perbuatan hukum pemindahan hak atas tanah yang dilakukan dengan sengaja supaya hak tersebut terlepas dari pemegangnya semula dan menjadi hak pihak lain. Terhadap pendaftaran tanah tersebut sebagaimana yang diatur dalam Pasal 40 Peraturan Pemerintah Nomor 24 Tahun 1997 Tentang Pendaftaran Tanah 
yakni:

(1) Selambat-lambatnya 7 (tujuh) hari kerja sejak tanggal ditandatanganinya akta yang bersangkutan, PPAT wajib menyampaikan akta yang dibuatnya berikut dokumen-dokumen yang bersangkutan kepada Kantor Pertanahan untuk didaftar.

(2) PPAT wajib menyampaikan pemberitahuan tertulis mengenai telah disampaikannya akta sebagaimana dimaksud pada ayat (1) kepada para pihak yang bersangkutan.

Kenyataan dalam prakteknya Pejabat Pembuat Akta Tanah di daerah Kota Banjarmasin sebagai pejabat umum yang diberi wewenang untuk membuat akta-akta dalam peralihan hak atas tanah, akta pembebanan serta surat kuasa pembebanan hak tanggungan, ternyata terjadi keterlambatan dalam proses pendaftarannya yang melebihi batas waktu 7 (hari) hari, setelah akta tersebut ditandatangani oleh para pihak, saksi dan Pejabat Pembuat Akta Tanah.

Berdasarkan hasil wawancara di Kantor Pertanahan Kota Banjarmasin dengan Kepala Seksi Peralihan dan Pendaftaran Hak Atas Tanah ${ }^{5}$. Masih adanya beberapa peralihan hak atas tanah yang sudah masuk di Kantor Pertanahan Kota Banjarmasin untuk didaftar, belum atau ada beberapa persyaratan peralihan hak tanah tersebut yang belum lengkap, sehingga mengalami keterlambatan dalam proses pembuatan Surat Perintah Setor, dan secara otomatis oleh pihak petugas loket berkas pendaftaran tersebut akan dikembalikan kepada pihak PPAT untuk dilengkapi kembali. Sehingga akan semakin lama kembali selang waktu pendaftaran akta peralihan

5 Hasil wawancara pribadi penulis dengan Haspian Noor, S.H., Kepala Seksi Pendaftaran dan Peralihan Hak Atas Tanah BPN Kota Banjarmasin. pada tanggal 02 Pebruari 2016 tersebut. Mengenai Ketentuan Pendaftaran tersebut dapat ditemukan pada Pasal 40 Peraturan Pemerintah Nomor 24 Tahun 1997 tentang Pendaftaran Tanah, menyatakan bahwa setelah Pejabat Pembuat Akta Tanah (PPAT) atau Pejabat Pembuat Akta Tanah Sementara (PPAT Sementara) membuat akta, selambat-lambatnya 7 (tujuh) hari kerja sejak tanggal ditandatanganinya akta tersebut, PPAT atau PPAT Sementara wajib menyampaikan akta yang dibuatnya berikut dokumendokumen yang bersangkutan kepada Kantor Pertanahan untuk didaftar. Meskipun penyerahan akta peralihan hak atas tanah ke Kantor Pertanahan Kota Banjarmasin sebagaimana yang dipraktekkan oleh sebagian besar PPAT di Kota Banjarmasin tersebut tidak sesuai dengan ketentuan perundang-undangan yang berlaku, namun tidak mengakibatkan batalnya akta yang dimaksud dan memang tidak ada satu ketentuan hukum pun yang menyatakan bahwa dengan keterlambatan penyerahan akta tersebut menjadikan akta yang bersangkutan batal.

Menurut Notaris dan PPAT "HG" yang berkedudukan di Kota Banjarmasin dengan keterlambatan pendaftaran peralihan hak atas tanah ke Kantor Pertanahan Kota Banjarmasin, akibat hukumnya tidak mengakibatkan proses dalam pendaftaran akta tersebut menjadi batal, akan tetapi akta tersebut masih terus diproses oleh Kantor Pertanahan Kota Banjarmasin sampai sertipikat yang mengalami keterlambatan tersebut ditandatangani oleh Kepala Kantor Pertanahan Kota Banjarmasin dan dapat diambil oleh PPAT yang bersangkutan. ${ }^{6}$ Walaupun pengirimannya terlambat, Kepala Kantor Pertanahan Kota

6 Hasil wawancara pribadi penulis denga $\mathrm{HG}$, Notaris dan PPAT Kota Banjarmasin, pada tanggal 28 Januari 2016. 
Banjarmasin tetap wajib memprosesnya. Tetapi PPAT yang bersangkutan bertanggung jawab terhadap semua akibat, termasuk kerugian yang diderita pihak-pihak yang bersangkutan, yang disebabkan oleh keterlambatan pengiriman berkas tersebut.

Hal inilah yang sedikit banyak telah mempengaruhi kinerja PPAT di Kota Banjarmasin dalam menyerahkan akta tersebut ke Kantor Pertanahan Kota Banjarmasin.Menurut ketentuan Pasal 103 ayat (4) Peratuan Menteri Negara Agraria/Kepala Badan Pertanahan Nasional Nomor 3 Tahun 1997 yang menyatakan bahwa ketentuan sebagaimana dimaksud pada ayat (2) dan (3) yang diterimakan kepada PPAT yang bersangkutan dan harus juga dilaksanakan oleh Kantor Pertanahan, walaupun pengiriman berkas oleh PPAT dilakukan sesudah waktu yang ditetapkan pada ayat (1).

Faktor-Faktor yang Menjadi Penghambat bagi PPAT dalam Melaksanakan Pendaftaran Akta Peralihan Hak

Pertama adalah hambatan yang dihadapi PPAT dalam proses pendaftaran akta Peralihan hak atas tanah. Hal ini seringkali terjadi dalam proses pendaftarannya, meskipun akta peralihan hak atas tanah sudah selesai dibuat, masih ada beberapa kendala yang terjadi. Pertama, pada saat akan mendaftarkan akta peralihan tersebut, ada beberapa persyaratan yang tidak bisa terpenuhi secara cepat dan tepat waktu, mengingat waktu yang telah ditetapkan oleh peraturan selambat-lambatnya 7 (tujuh) hari sudah dilakukan pendaftaran, contohnya; mengenai data diri (KTP) para penghadap yang batas berlakunya sudah habis, sedangkan syarat untuk pendaftaran akta peralihan tersebut salah satunya adalah data diri penghadap (KTP) yang masih berlaku, untuk mengurus agar syarat tersebut dapat terpenuhi membutuhkan waktu kembali untuk melengkapi syarat tersebut. Data diri (KTP) yang masih berlaku ini hanya sebagai lampiran tambahan untuk pendaftaran akta peralihan pada kantor pertanahan. Kedua, adanya keteledoran pihak PPAT, tidak sabar menunggu proses pengecekan selesai terhadap keabsahan sertifikat di Kantor Pertanahan, dengan melakukan penandatangan akta peralihan terlebih dahulu, sehingga selang waktu selesai antara proses pengecekan sertifikat dengan proses pandaftaran akta peralihan hampir berbarengan. Ketiga, yang dikarenakan PPAT tersebut tidak bisa memanajemen waktu dan banyaknya pekerjaan, sehingga tidak dapat mengejar waktu yang sudah ditetapkan oleh peraturan, dan yang lebih sering terjadi, mengesampingkan syarat-syarat selain syarat untuk pembuatan akta peralihan yang lebih penting terlebih dahulu untuk dilengkapi, ketimbang syarat yang lain, misalkan saja Kartu Keluarga, foto copy SPPT PBB tahun berjalan atau adanya ijin dari pihak yang berwenang apakah hak tersebut dapat dialihkan atau tidak.

Kedua, hambatan-hambatan yang timbul dari faktor intern, dalam hal ini pada Kantor Pertanahan Kota Banjarmasin, dibedakan menjadi dua yakni hambatan dalam segi teknis atau pelaksana dan hambatan dalam segi pembukuan.

1. Hambatan dalam segi teknis atau pelaksana, maksudnya hambatan yang dilihat dari segi pelaksana, dalam hal ini menyangkut sumber daya manusia, diantaranya

a. Kurangnya sumber daya manusia, dalam hal ini tenaga ahli di bidang pertanahan, yang menangani pendaftaran peralihan hak atas tanah tersebut pada Sub Seksi peralihan hak, pembeba- 
nan dan PPAT. Pelaksanaan pelayanan pendaftaran peralihan hak atas tanah bukan merupakan pekerjaan yang ringan akan tetapi merupakan pekerjaan yang berat yang banyak membutuhkan tenaga ahli di bidangnya. Di Kantor Pertanahan Kota Banjarmasin ini, jumlah tenaga ahli yang menangani pelaksanaan pendaftaran peralihan hak atas tanah karena jual beli, hibah, tukar menukar, pembagian hak bersama, pemasukan ke dalam perusahaan/ inbreng ini masih sangat terbatas.Hal ini dilihat dari menumpuknya pekerjaan pendaftaran peralihan hak atas tanah ini, yang menyebabkan pelayanan menjadi sangat lambat dan tidak tepat waktu. Begitu juga pada petugas pengukuran, jika dalam hal tanah yang dialihkan tersebut belum bersertipikat, walaupun sudah ada petugas ukur keliling yang sudah terjadwal, sering juga terlambat dalam melakukan pengukuran, dikarenakan jumlah tenaga ukur sangat terbatas. Keterlambatan ini dikarenakan banyaknya pekerjaan dari petugas ukur yang lebih penting dari pada pengukuran di lapangan yang akhirnya pekerjaan pengukuran menjadi tertunda.

b. Benturan kepentingan pegawai antara kepentingan pekerjaan dengan kepentingan pribadinya, yang keduanya sama-sama penting. Kurangnya tenaga ahli dalam pekerjaan ini menyebabkan terjadinya benturan kepentingan antara kepentingan pribadi pegawai dengan kepentingan pekerjaan, yang keduanya dirasakan terlihat penting.Hal ini pula yang menyebabkan pelaksanaan pendaftaran peralihan hak atas tanah ini tidak lancar, dan menghambat waktu penyelesaiannya.

c. Kesibukan Kepala Kantor Pertanahan dalam hal ini Kantor Pertanahan Kota Banjarmasin. Pekerjaan Kepala Kantor Pertanahan Kota Banjarmasin sangat padat. Kesibukannya terkadang menunda pekerjaan ini untuk beberapa waktu lamanya, karena dirasakan ada sesuatu kepentingan yang harus diselesaikan terlebih dahulu, yang sangat penting dari pekerjaan lain. Misalnya: pertama, untuk kepentingan dinas, yang mengharuskan Kepala Kantor Pertanahan meninggalkan semua pekerjaan di Kantor Pertanahan tersebut. Sehingga waktu penyelesaian pekerjaan ini menjadi tertunda sampai beberapa waktu yang lama. Hambatan dari segi teknis atau pelaksana ini menyebabkan pandangan masyarakat menjadi negatif mengenai pelaksanaan pendaftaran peralihan hak atas tanah di Kantor Pertanahan Kota Banjarmasin. Kedua, karena sekarang menggunakan sistem online, dan sudah barang tentu mengetahui bahwa ada hubungan erat dengan aliran listrik, dimana untuk daerah Banjarmasin sering sekali terjadi pemadaman listrik baik yang sudah terjadwal atau yang terjadi karena faktor alam. Atau dengan lambatnya sistem tersebut karena semua pengaturan dilakukan oleh pusat. Ketiga, dengan adanya sumber daya manusia yang masih sangat terbatas,Kepala Sub Seksi peralihan hak, pembebanan dan PPAT memang mengakui, bahwa merupakan sebagian sebab dari belum lancarnya kegiatan pelaksanaan pendaftaran peralihan hak atas tanah 
tersebut di Kantor Pertanahan Kota Banjarmasin. Maka wajarlah kiranya dengan kekurangan tenaga ahli, penyelesaian pekerjaan ini menjadi terlambat karena kurang adanya keseimbangan antara tenaga yang tersedia dan tugas yang harus diselesaikan. ${ }^{7}$

2. Dari segi pembukuan, maksudnya hambatan yang dilihat dari segipembukuannya atau pencatatannya, diantaranya: a. Pencarian buku tanah yang tidak ditemukan Ketika PPAT akan melakukan pendaftaran peralihan hak atas tanah tersebut, terlebih dahulu harus dicari buku tanah yang sesuai dengan sertipikat yang bersangkutan, untuk mengetahui apakah data-data yang ada dalam sertipikat sesuai dengan data-data yang ada dalam buku tanah yang bersangkutan sekaligus untuk mencatat adanya peralihan dan hapusnya hak atas tanah khususnya karena jual beli, hibah, tukar menukar,pembagian hak bersama, pemasukan kedalam perusahaan/inbreng dan lain-lain. Dalam pencarian buku tanah tersebut kadangkadang mengalami hambatan, diantaranya tidak ditemukannya buku tanah pada almari arsip buku tanah, hal ini dikarenakan buku tanah yang bersangkutan sedang dipakai/digunakan oleh bagian lain dan belum dikembalikan pada almari arsip buku tanah.

b. Pengisian akta-akta khususnya akta peralihan hak yang dibuat oleh PPAT yang kurang lengkap, kurang teliti dan cenderung tidak sempurna dalam pem-

7 Hasil wawancara pribadi penulis dengan Antung Rini Setiawati,S.H., MKn Kepala Sub Seksi Kantor Pertanahan Kota Banjarmasin, pada tanggal 02 Pebruari 2016. buatan aktanya.

c. Berkas-berkas yang diperlukan untuk melakukan pendaftaran akta peralihan hak atas tanah karena tersebut, tidak lengkap atau kurang lengkap.

d. Tanah yang akan dilaksanakan pendaftaran peralihannya tersebut ternyata dalam keadaan sengketa.

Ketiga, hambatan-hambatan yang timbul karena faktor ekstern, dalam hal ini dari masyarakat Kota Banjarmasin diantaranya:

1. Banyaknya peralihan hak atas tanah yang dilakukan di bawah tangan yang hanya bermodalkan materai.

2. Masih minimnya pengetahuan masyarakat akan arti pentingnya pendaftaran peralihan hak atas tanah tersebut.

3. Bagi masyarakat pedesaan, biaya untuk melakukan peralihan hak atas tanah sampai didaftarkan peralihan hak tersebut sangat mahal.

4. Banyak masyarakat di pedesaan yang dalam melakukan pendaftaran peralihan hak atas tanahnya melalui Kepala Desa, yang terkadang karena kesibukan Kepala Desa mengakibatkan pendaftaran peralihan hak atas tanah menjadi tertunda.

Keempat, hambatan yang dihadapi masyarakat adalah:

1. Kurangnya Pemahaman Masyarakat. Dari pengamatan penulis, menunjukkan kurangnya pemahaman masyarakat akan arti pentingnya pelaksanaan pendaftaran peralihan hak milik atas tanah. Masih banyaknya masyarakat, khususnya daerah pinggiran Kota Banjarmasin yang dalam melakukan peralihan hak atas tanahnya melalui jual beli yang dilakukan di bawah tangan, tidak dilakukan di hadapan PPAT.

2. Biaya Pendaftaran Yang Mahal 


\section{Upaya Kantor Pertanahan Kota Banjarmasin Mengatasi Hambatan}

Upaya untuk mengatasi hambatan yang dilakukan oleh Kantor Pertanahan dari segi internal adalah: (1) Membuat pengumuman-pengumuman kepada setiap kecamatan yang berada di wilayah Banjarmasin, tentang informasi-informasi baik mengenai pendaftaran peralihan hak atas tanah melalui jual beli, hibah, tukar menukar maupun pemasukan dalam perusahaan/inbreng maupun pendaftran tanah untuk pertama kalinya, dan (2) Memberikan pemahanan-pemahaman kepada mayarakat lewat kepala desa/kelurahan tentang informasi pendaftaran tanah dan besar biaya pendaftaran tanah tidak akan lari dari peraturan pemerintah yang berlaku. Upaya dari segi eksternal adalah: (1) Penyuluhan langsung oleh pihak Pegawai Kantor Pertanahan Kota Banjarmasin, dan (2) One Day Service.

Sanksi yang Diterapkan terhadap Pejabat Pembuat Akta Tanah yang Mendaftarkan Aktanya Melebihi Jangka Waktu 7 (Tujuh) Hari

Menurut Pasal 62 Peraturan Pemerintah Nomor 24 Tahun 1997 tentang Pendaftaran Tanah:

"PPAT yang dalam melaksanakan tugasnya mengabaikan ketentuan-ketentuan sebagaimana dimaksud dalam Pasal 38, Pasal 39 dan Pasal 40 serta ketentuan dan petunjuk yang diberikan oleh Menteri atau Pejabat yang ditunjuk dikenakan tindakan administratif berupa teguran tertulis sampai pem-berhentian dari jabatannya sebagai PPAT, dengan tidak mengurangi kemungkinan dituntut ganti kerugian oleh pihak-pihak yang menderita kerugian yang diakibatkan oleh diabai- kannya ketentuan-ketentuan tersebut."

Berdasarkan hasil wawancara dengan Kepala Seksi Pendaftaran dan Peralihan Hak Kantor Pertanahan Kota Banjarmasin, bahwa sampai sejauh ini sanksi administratif yang pernah diberikan hanyalah teguran lisan dan teguran tertulis saja, untuk pemberhentian sementara dari jabatan dan pemberhentian jabatan belum di tindak secara tegas oleh Kepala Kantor Pertanahan Kota Banjarmasin. ${ }^{8}$

Mengenai sanksi yang dapat dikenakan terhadap PPAT juga ditetapkan dalam Pasal 6 ayat (1) Kode Etik PPAT yakni bagi anggota yang melakukan pelanggaran Kode Etik dapat dikenai sanksi berupa9

1. Teguran;

2. Peringatan;

3. Schorsing (pemecatan sementara) dari keanggotaan IPPAT;

4. Onzetting (pemecatan) dari keanggotaan IPPAT;

5. Pemberhentian dengan tidak hormat dari keanggotaan IPPAT.

Untuk sanksi bagi Kepala Kantor Pertanahan itu sendiri apabila terlambat menyelesaikan proses peralihan maka diberikan sanksi berupa penilaian kerja, yakni peringkat kinerja yang berarti kalau kinerja buruk maka akan mendapat penurunan peringkat yang dihitung dari keseluruhan kantor Badan Pertanahan Nasional seluruh tanah air. ${ }^{10}$

8 Hasil wawancara pribadi penulis dengan Haspian Noor, S.H., Kepala Seksi Pendaftaran dan Peralihan Hak Atas Tanah BPN Kota Banjarmasin, pada tanggal 02 Pebruari 2016

9 Anonim. 2009 Himpunan Peraturan Perundangundangan Jabatan Notaris \& PPAT. Cet.II, Jakarta: Indonesia Legal Center Publishing, hlm. 353

10 Hasil wawancara pribadi penulis dengan Antung Rini Setiawati,S.H., MKn Kepala sub Seksi Kantor Pertanahan Kota Banjarmasin, Pada tanggal 02 Pebruari 2016. 


\section{PENUTUP}

\section{Kesimpulan}

Berdasarkan uraian penulis dapat disimpulkan sebagai berikut:

1. Akibat hukum lewatnya batas waktu pendaftaran akta peralihan hak tanah, tidak mengakibatkan batalnya akta peralihan hak atas tanah, akta peralihan tetap bisa didaftarkan pada Kantor Pertanahan. Terjadinya keterlambatan dalam dalam pendaftaran akta peralihan tidak terlepas dari adanya hambatan-hambatan yang terjadi dalam pelaksanaan pendaftaran peralihan hak atas tersebut, baik itu dari pihak PPAT, yang dikarenakan tidak lengkapnya berkas maupun dari pihak BPN sendiri baik karena faktor intern yaitu dari segi teknis (pelaksana) yaitu kurangnya sumber daya manusia/tenaga ahli, benturan kepentingan pegawai antara kepentingan pekerjaan dan kepentingan pribadi, dan dari segi pembukuan diantaranya pencarian buku tanah yang tidak ditemukan, pengisian akta-akta peralihan yang kurang lengkap dan sempurna, berkas yang diperlukan tidak lengkap serta tanah yang akan dialihkan haknya tersebut dalam keadaan sengketa.

2. Sanksi yang diberikan oleh Kepala Kantor Pertanahan Kota Banjarmasin kepada PPAT bahwa sampai sejauh ini sanksi administratif yang pernah diberikan hanyalah teguran lisan dan teguran tertulis saja, untuk pemberhentian sementara dari jabatan dan pemberhentian jabatan belum di tindak secara tegas, terkecuali dikarenakan akibat dari keterlambatan pendaftaran akta peralihan hak tersebut mengaki- batkan kerugian yang sangat merugikan para pihak sehingga masalah tersebut sampai pada ranah hukum dan putusanpun menjadikan seorang PPAT harus menjadi terdakwa ataupun terpidana barulah pihak Kantor Pertanahan Kota Banjarmasin bertindak tegas.

\section{Saran}

Untuk para Pejabat Pembuat Akta Tanah, harus benar-benar tertib administrasi, jangan melakukan penomoran terhadap akta peralihan yang dibuat sebelum persyaratan untuk itu lengkap, tugas utama PPAT adalah hanya membuatkan akta saja, para pihak sendiri yang melakukan proses pendaftaran akta peralihan hak ke Kantor Pertanahan, agar peralihan hak tersebut lebih cepat prosesnya sehingga mendapat jaminan kepastian hukum serta mempunyai kekuatan hukum yang tetap, dan untuk Kantor Badan Pertanahan Kota Banjarmasin, hendaknya meningkatkan kwantitas stafnya yang menangani pendaftaran peralihan hak atas tanah tersebut dan meningkatkan produktifitas kerja, sehingga kinerja Kantor Badan Pertanahan Kota Banjarmasin berkesan sangat baik dan lancar.

1. Pihak Kantor Badan Pertanahan hendaknya selalu mengawasi dan melakukan pembinaan kepada para PPAT serta benar-benar melaksanakan ketentuan dari peraturan pemerintah tersebut secara tegas dan menerapkan sanksi jangan hanya berupa teguran baik itu secara lisan maupun tulisan, tapi harus lebih menjurus kepada sanksi yang membuat efek jera sehingga para PPAT lebih berhati-hati, teliti dan tertib administrasi dalam bekerja, dan ini akan menjadi nilai tambah juga terhadap kinerja BPN. 


\section{BIBLIOGRAPY}

Anonim. 2009 Himpunan Peraturan Perundangundangan Jabatan Notaris \& PPAT, Cet.II. Jakarta: Indonesia Legal Center Publishing.

Hadi, Soetrisno. 1985. Metodologi Research Jilid II. Jogjakarta: Yayasan Penerbit Fakultas Psikologi UGM

Ali, Zainuddin. 2009. Metode Penelitian Hukum. Jakarta: Sinar Grafika

\section{Peraturan Perundang-undangan}

Undang-Undang Dasar Negara Republik Indonesia Tahun 1945

Undang-Undang Nomor 5 Tahun 1960 tentang Undang-Undang Pokok Agraria

Peraturan Pemerintah Nomor 24 Tahun 1997 tentang Pendaftaran Tanah

Peraturan Pemerintah Nomor 37 Tahun 1998 tentang Jabatan Pejabat Pembuat Akta Tanah (PPAT)
Keputusan Presiden Nomor 10 Tahun 2001 tentang Pelaksanaan Otonomi Daerah Di Bidang Pertanahan

Peraturan Menteri Negara Agraria/Kepala Badan Pertanahan Nasional Nomor 3 tahun 1997 tentang Peraturan Pelaksanaan

Peraturan Menteri Negara Agraria Nomor 1 Tahun 2006 tentang Ketentuan Pelaksanaan

Peraturan Pemerintah Nomor 37 Tahun 1998 tentang Peraturan Jabatan Pejabat Pembuat Akta Tanah;

Peraturan Menteri Agraria Nomor 3 Tahun 1997 tentang Ketentuan Pelaksanaan

Peraturan Pemerintah Nomor 24 Tahun 1997 tentang Pendaftaran Tanah 